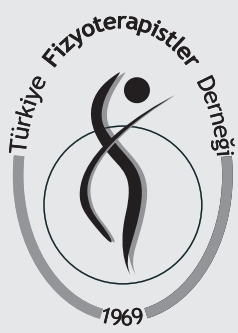

Türk Fizyoterapi ve Rehabilitasyon Dergisi

$201526(2) 86-92$

Burcu Semin AKEL, Doç.Dr.Fzt ${ }^{1}$ Aynur DEMIREL, Uz.Fzt² Gül BALTACI, Prof. ${ }^{2}$

Geliş Tarihi: 21.07.2014 (Received) Kabul Tarihi: 07.08.2015 (Accepted)

İletişim (Correspondence):

Aynur DEMIREL

Hacettepe Üniversitesi, Sağlık Bilimleri Fakültesi, Fizyoterapi ve rehabilitasyon bölümü, Sporcu Sağlığı Ünitesi, 06100 , Ankara, Türkiye

Tel: 90-312-3052525/186

Gsm: 05545295057

FAX: 90-312-3052012

e-mail:aynur.demirel@hacettepe.edu.tr

1 Hacettepe Üniversitesi, Sağlık Bilimleri Fakültesi, Ergoterapi Bölümü, 06100, Ankara, Türkiye

2 Hacettepe Üniversitesi, Sağlık Bilimleri Fakültesi, Fizyoterapi ve rehabilitasyon bölümü, Sporcu Sağlı, 06100, Ankara, Türkiye

\section{DETERMINATION OF GRIP CONTACT AREAS WITH STEREOLOGIC MEASUREMENT IN CHILDREN WITH HEMIPARETIC CEREBRAL PALSY}

\section{RESEARCH ARTICLE}

\section{ABSTRACT}

Purpose: The aim of the study is to present a method used to estimate hand and finger contact areas on different sized objects and compare results of children with Cerebral Palsy (CP) with healthy peers.

Methods: A total of 51 children, 26 with hemiparetic CP classified as I or II according to Manuel Ability Classification System and had 1 or $1+$ level spasticity as to Modified Ashworth Scale and 25 healthy peers were included to the study. The contact area was calculated by the Cavalieri principle of stereological estimation after children grasped cylindrical objects having diameters of $2.5,4$ and $5 \mathrm{~cm}$.

Results: The contact areas were found to be different at the thenar side for the grasped object with $2.5 \mathrm{~cm}$ diameter, and at the hypothenar side for the objects with 4 and $5 \mathrm{~cm}$ diameters $(p<0.05)$.

Discussion: Clinicians are more interested with thumb since the contribution of adductor spasticity in CP. However, hypothenar contribution should be also considered especially with objects having larger diameters. The data gained from the study can guide rehabilitation efforts towards improving hand function.

Keywords: Cerebral Palsy; Hand; Muscle Spasticity; Hand Strength

HEMIPARETIK SEREBRAL PALSI'Li ÇOCUKLARDA KAVRAMA TEMAS ALANININ STEREOLOJIK YÖNTEMLE BELIRLENMESi

\section{ARAŞTIRMA MAKALESI}

\section{ÖZ}

Amaç: Çalışmanın amacı farklı boyuttaki objelerde parmak ve el temas alanını hesaplamak için bir yöntem sunmak ve Serebral Palsi'li çocukların sonuçlarını sağlıklı grupla karşılaştırmaktır.

Yöntemler: Manuel yetenek sınıflama sistemi'ne göre I veya II kavrama seviyesi bulunan, Modifiye Ashworth Skalasına göre 1 ya da $1+$ seviyelerinde spastisiteye sahip olan 26 hemiparetik Serebral Palsi'li ve 25 sağlıklı toplam 51 çocuk çalışmaya alınmıştır. Çapları 2,5, 4 ve $5 \mathrm{~cm}$ olan silindirik objeler çocuklar tarafından kavrandıktan sonra temas alanları Cavalieri prensibi stereolojik ölçüm yöntemi ile hesaplanmıştır.

Sonuç: Kavrama temas alanı 2,5 cm çaplı obje üzerinde tenar bölgede, 4 ve $5 \mathrm{~cm}$ çaplı obje üzerinde ise hipotenar bolgede istatistiksel olarak farklı bulunmuştur $(p<0.05)$.

Tartışma: Klinisyenler Serebral palside adduktor spastisitesi nedeniyle baş parmakla daha fazla ilgilenmektedir. Buna karşın, özellikle büyük çaplı obje kavraması sırasında dikkat hipotenar bölgeye de verilmelidir. Çalışma ile elde edilen veriler el fonksiyonunu geliştirmede yol gösterebilir.

Anahtar kelime: Serebral Palsi; El; Kas Spastisitesi; El kuvveti 


\section{INTRODUCTION}

In hemiparetic Cerebral Palsy (CP), unilateral damage of motor cortex and/or pyramidal tract causes a strong asymmetry between body sides, which is manifested irregular and jerky movements on the impaired body side (1) . Eighty-seven per cent of children were considered to be independent in age-relevant manual activities, however independent skilled finger movements do not develop properly. Therefore, these children often find adaptive strategies to compensate for a poor bimanual ability $(2,3)$.

When children with hemiparetic CP are asked to grasp an object with the impaired arm, they usually grasp with the entire hand, using a slow and clumsy power grasp, do not develop the parallel coordination of grip force and load force like nondisabled children due to hyperactive stretch reflexes and hypertonia accompanying spasticity $(2,4,5)$. The movement pattern is occurred by an increased number of submovements, increased variability of hand trajectories, inappropriately coordinated force levels in the hand and fingers $(2,4)$.

Previous studies showed decreased elbow extension and supination, increased trunk movements during activities in hemiplegic CP (6-11). Additionally, altered scapular and shoulder movements that related with altered muscle tone, weakness and inhibition of rotator cuff muscles and spasticity in pectoralis major muscle were recorded (10). Affected side is found to be slower than unaffected side and distal control of the movement was more prominent than proximal control (12). Studies which aiming to evaluate distal movements and grasping in CP were mostly conducted about hand functioning, reaching and holding, finger positioning and strength $(1,2,13-15)$. However grasping itself involves all the components including reaching and holding, finger positioning, contacting with the object, strength and releasing.

Contacting with an object is one of the important components that gives information of manipulatory experience, control of fingers and hand, tactile feedback, grasping pattern. However, contact area has not calculated for children with hemiparetic $C P$. During simple observation or hand function assessments, we are not aware of how the child contacts with the object. For evaluation of grip contact area, approximation is usually used as a subjective assessment (15). Qualitative outcome measures are used in clinics which only provide a subjective description based on the assessor who visually scores the range and quality of movement during task execution (5). Quantitative outcome measures are based on technical measures and calculations, e.g. joint angles, movement duration, and speed (14).

Recently the Cavaliere principle that is a stereological volume estimation method has been applied as an aid in the assessment of radiological images. This approach allows the evaluation of the area and volume of any object on the bias of physical sections $(16,17)$. In this study applicability of this method in calculating hand contact area will be discussed.

The aims of the study were: 1 . Calculating contact area in hemiparetic CP to gain better understanding of the child's selective disuse while grasping and 2. Analyzing the grasping pattern on three objects with different dimensions to understand the effect of object size on grasping pattern. It was hypothesized that contact area of impaired and unimpaired hand will show different contacting patterns than normal children and the contact area will change according to object size.

\section{MATERIAL AND METHODS}

\section{Participants}

Twenty six children with hemiparetic CP (12 female and 14 male), aged between 5 and 12 years (mean age 9,09 $\pm 4,9$ years) without any cognitive problem and, 25 healthy children aged between 6 and 12 years (mean age 10,9 $\pm 3,0$ years) (13 female and 12 male) participated in this study. Fifteen of the children with CP had right and 11 of them had left side hemiplegia. All participants had normal vision and hearing. The inclusion criterion for children with CP was to be classified as I or II according to the Manuel Ability Classification System (MACS) (18) so that they can do prehension with their impaired hand. They also did not have any extra problems affecting the function of the hand including fracture, burn, injury etc. Children with $\mathrm{CP}$ were excluded from the study if they had any neuromuscular disorders which is characterized pain in either of their upper limbs, a visual impairment, thumb-in palm deformity, spasticity in 
flexor and pronator muscles above 1- 1+ according to Modified Ashworth spasticity scale or could not adhere to the required task. The exclusion criteria for healthy children were having a hand disorder, pain in upper limbs, actively involvement in sports.

Prior to participation in the study, participants and their families gave informed consent. This study was performed in accordance with the principles laid down in the Helsinki Declaration and with the ethical advisory committee of the University Ethical Research Committee.

\section{Procedure}

Demographic characteristics of the children were recorded. The power grip where the palm forms a jaw of a clamp with the other digits was selected to be measured. In studies, power grip was also preferred mostly (5).

\section{Experimental set-up}

Participants were seated comfortably in front of an adjustable table. Three cylindrical objects having diameters of $2,5 \mathrm{~cm}, 4 \mathrm{~cm}$ and $5 \mathrm{~cm}$ were wrapped with paper for every single test. The object asked to be handled was positioned in front of the participants' body midlines. For a pilot trial, participants were asked to grasp and release the object having diameter of $5 \mathrm{~cm}$. with both hands. They were instructed to grasp the object with the power grip while the wrist was in neutral position. This condition helped to standardize the initial hand orientation imposed at the start of each trial.

The experimental task was carefully explained and demonstrated to each child. For real test, palmar surface of the hand and fingers were painted with finger paint. Children with CP were asked to grasp the object first with unimpaired, then with impaired hand. Healthy children used dominant hand. We asked participants to pick up the object on the table, lift it and hold it for 4 to 5 seconds, then put it on the table and release the hand. Participants began each trial with the hand resting in a prescribed orientation before reaching out to pick up the object. Paint was renewed for all tests. The data were analyzed from the sheet of paper which was grasped by the participant.

We examined both impaired and unimpaired hand's grasping contact area because bimanual activities for grasping were advised in pediatric rehabili- tation setting for CP (19). Even it was diagnosed as hemiparetic CP, we assumed that bimanual activities were affected. Therefore it was aimed to evaluate both hands contact area and compare with healthy children. Measurements of impaired hand was named as Group I, unimpaired hand was named as Group II and healthy children was named as Group III.

\section{Stereological measure}

Contact area was calculated with Cavalieri principle of stereological estimation as described in the previous studies. This method is standardized while measuring area and volume. For calculating areas, the sheet of paper with fingerprints was taken out from the cylinders after each trial. The contact area for the entire hand and fingers separately obtained from the sheet was measured with transparent worksheets. At this point for scientific purposes, approach of stereological methods could be an alternative way for the evaluation of grasping and contacting patterns. In order to estimate the area, a common point counting grid with $1 / 4$ area fraction was used. This grid system was superimposed covering the surface area and both the circled and non-circled points $(0,25 \mathrm{~cm}$ distance between test points) were counted for the estimation of total hand and finger contact area (Figure 1). Previously defined corner of the crosses in the grid (i.e. upper right corner) was assessed as the point. The number of points (i.e. corners) hitting the examined structure was recorded for the stereological estimates. The following Formula was used to estimate the area by counting the intersecting points between the grids and the regions of interest $(16,17)$.

$A=a(p) \times \sum P(1)$

a (p) : The area represented by a point in the grid $(0,25 \mathrm{~cm})$

$\Sigma \mathrm{P}$ : Total number of points hitting the surface area of sections

\section{Statistical analysis}

All statistical tests were done using SPSS version 15.0. Group I and Group II was compared with Wilcoxon signed-rank test, whereas comparison with dominant hand of Group III was done with Mann-Whitney U test. Kruskall-Wallis was used to state total contact area differences measured on 
objects with different diameters. All the tests were two-tailed and conducted at the 5\% significance level.

\section{RESULTS}

Children with CP made more slips on the paper and paint was more significant on the radial side with the impaired hand than the unimpaired hand due to the increased force exerted with the impaired hand. The placements of the fingers and deviations of fingers to ulnar or radial side could also be observed from the fingerprints. The quality of gripping by means of usage of the hand during grasping could be understood objectively by getting the fingerprints of the participants.

Total contact area was found to be less for the Group I compared to Group II and Group III. Group I and Group III were different $(p<0.05)$. Also, the difference was found between Group I and group II within the object having diameter of $4 \mathrm{~cm}(p=0.04)$ and group II and group III within the objects having diameter of 4 and $5 \mathrm{~cm}(\mathrm{p}<0.05)$ (Table 1).

Different grasping patterns were found in contact areas of fingers on different sized objects. When grasping the object having diameter of $2,5 \mathrm{~cm}$, thumb was contacted with the object more in group I and ulnar side of the hand contacted less in group I and II. The difference was statistically significant

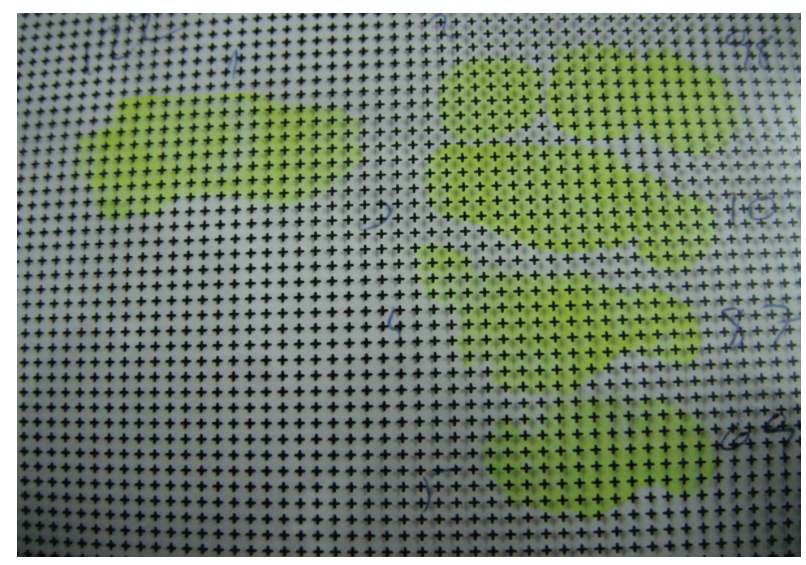

Figure 1: Estimation of the area of the hand contact using a transparent point grid

compared to group III (Table 1, Figure 2). The difference was found in contact area of the fingers of the group I except thumb while grasping the object having diameter of $4 \mathrm{~cm} .(p<0.05, p<0.01)$ (Table 1 , Figure 3 ). The grasping pattern in group II was similar in group III however there were differences between 2nd, 3rd and 5th fingers $(p<0.05)$ (Table 1, Figure 3).

The contact area pattern on the object having diameter of $5 \mathrm{~cm}$ is shown in Figure 4. Results showed differences in contact areas of 1 st and 2 nd fingers between group III and both groups I and II. $(p<0.05)$ (Table 1). The ulnar side of the hand in group I and II was contacted less while grasping, however the

Table 1: Comparison of contact area measurements between groups

\begin{tabular}{|c|c|c|c|c|c|c|c|}
\hline & & $\begin{array}{c}\text { Group I } \\
(n=25) \\
X \pm S S\end{array}$ & $\begin{array}{c}\text { Group II } \\
(n=25) \\
X \pm S S\end{array}$ & $\begin{array}{c}\text { Group III } \\
(n=26) \\
X \pm S S\end{array}$ & $\begin{array}{c}\text { Group I-II } \\
\mathbf{p}\end{array}$ & $\begin{array}{c}\text { Group I-III } \\
\text { P }\end{array}$ & $\begin{array}{c}\text { Group } \\
\text { II-III } \\
\text { p }\end{array}$ \\
\hline \multirow{6}{*}{ 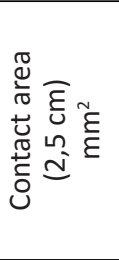 } & Total hand & $87.70 \pm 26.71$ & $92.80 \pm 27.41$ & $103.28 \pm 31.54$ & 0.37 & $0.04 *$ & 0.17 \\
\hline & 1st finger & $18.10 \pm 7.15$ & $14.99 \pm 5.03$ & $11.75 \pm 7.79$ & $0.04 *$ & $0.04 *$ & $0.02 *$ \\
\hline & 2nd finger & $22.80 \pm 9.00$ & $18.96 \pm 9.32$ & $23.21 \pm 7.81$ & $0.04^{*}$ & 0.28 & 0.11 \\
\hline & 3rd finger & $20.01 \pm 7.87$ & $21.03 \pm 9.4$ & $23.59 \pm 9.17$ & 0.69 & $0.03 *$ & 0.31 \\
\hline & 4th finger & $18.28 \pm 9.46$ & $18.75 \pm 7.87$ & $25.32 \pm 10.18$ & 0.80 & $0.007^{*}$ & $0.01 *$ \\
\hline & 5th finger & $11.02 \pm 8.08$ & $12.44 \pm 7.72$ & $19.11 \pm 7.53$ & 0.76 & $0.02^{*}$ & $0.005^{*}$ \\
\hline \multirow{6}{*}{ 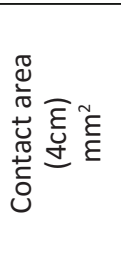 } & Total hand & $96.69 \pm 28.38$ & $111.13 \pm 40.56$ & $131.61 \pm 35.51$ & $0.04 *$ & $<0.01^{*}$ & $0.03 *$ \\
\hline & 1st finger & $23.99 \pm 6.57$ & $21.87 \pm 6.33$ & $21.42 \pm 8.81$ & 0.08 & 0.88 & 0.49 \\
\hline & 2nd finger & $22.91 \pm 9.51$ & $22.31 \pm 9.67$ & $28.59 \pm 9.63$ & 0.73 & $0.03^{*}$ & $0.02 *$ \\
\hline & 3rd finger & $22.27 \pm 9.60$ & $25.29 \pm 10.1$ & $30.28 \pm 8.12$ & 0.14 & $0.001^{*}$ & $0.04 *$ \\
\hline & 4th finger & $18.80 \pm 10.46$ & $23.29 \pm 9.53$ & $27.67 \pm 9.17$ & $0.03 *$ & 0.009* & 0.09 \\
\hline & 5th finger & $12.84 \pm 9.28$ & $18.48 \pm 6.87$ & $22.84 \pm 7.73$ & $0.04 *$ & $0.005^{*}$ & $0.006 *$ \\
\hline \multirow{6}{*}{ 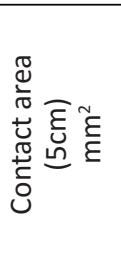 } & Total hand & $100.43 \pm 35.86$ & $106.91 \pm 39.53$ & $135.51 \pm 25.89$ & 0.30 & $0.01^{*}$ & $0.04 *$ \\
\hline & 1st finger & $20.32 \pm 6.80$ & $20.93 \pm 9.11$ & $24.32 \pm 7.11$ & 0.70 & $0.02 *$ & $0.04 *$ \\
\hline & 2nd finger & $20.01 \pm 11.39$ & $21.36 \pm 9.43$ & $27.32 \pm 7.97$ & 0.38 & $0.01 *$ & $0.02 *$ \\
\hline & 3rd finger & $22.59 \pm 13.11$ & $25.11 \pm 9.53$ & $28.26 \pm 8.09$ & 0.27 & 0.11 & 0.20 \\
\hline & 4th finger & $19.70 \pm 9.60$ & $23.33 \pm 8.46$ & $26.63 \pm 8.76$ & $0.04 *$ & $0.01^{*}$ & 0.17 \\
\hline & 5th finger & $13.98 \pm 9.54$ & $17.51 \pm 9.15$ & $22.03 \pm 9.08$ & 0.06 & $0.003^{*}$ & 0.09 \\
\hline
\end{tabular}




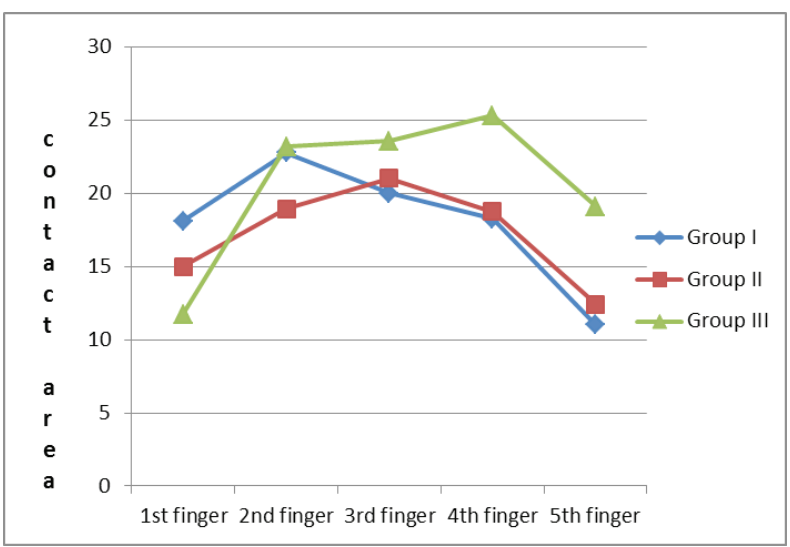

Figure 2: Contact area pattern on cylinder with $2,5 \mathrm{~cm}$ diameter

difference was only found for the group I $(p<0.05)$ (Table 1).

When the total contact areas were compared between objects, there was a difference only between the objects having diameter of $2.5 \mathrm{~cm}$ and $5 \mathrm{~cm}$ $(p=0.035)$.

\section{DISCUSSION}

The main question we pursued in the present study was in which way children with hemiparetic CP contact with different sized objects. We hypothesized that children with $\mathrm{CP}$ would present wider contact actions, compared to actions performed with their unimpaired hand and healthy subjects. It is important to note that our findings regarding the interaction with the object while grasping have been shown with a new method that could be used to estimate finger and hand contact areas and address grasping impairments.

In manipulative movements, the original control mechanisms of infants are not transformed in children with CP. They retain an immature (inefficient) pattern of muscle co-ordination, have a general deficit in the scaling of fingertip forces or develop an abnormal pattern because of pathological or compensatory mechanisms (2). Data about contacting with the object would give valuable information to state abnormal patterns or adjustments of the hand while grasping. Therefore, hand orientation during handling the object was investigated in this study.

By measuring the contact area, it was thought that the shaping of the fingers and palmar concavity would be monitorized. This easy and simple method

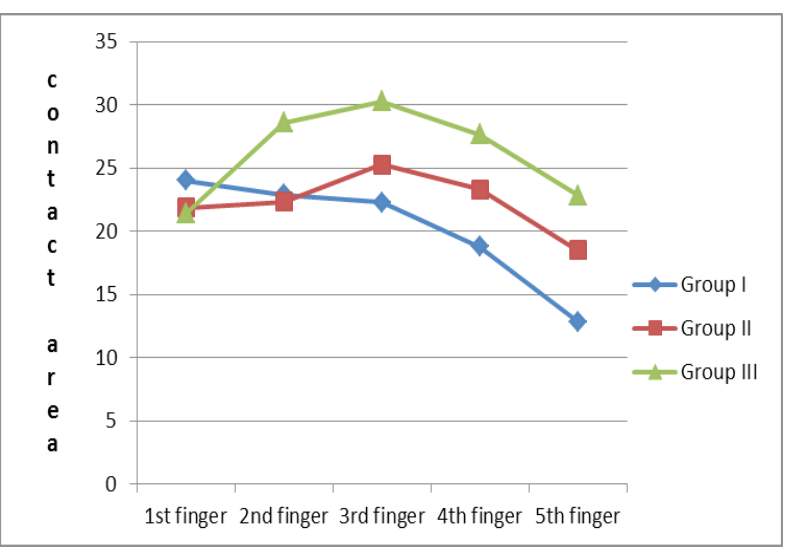

Figure 3: Contact area pattern on cylinder with $4 \mathrm{~cm}$ diameter

used to obtain contact areas showed characteristics of the fingers in contact. The quality of grasping could be understood objectively by getting the fingerprints of the participants. When checking the prints in terms of paint quality, placement and deviations of fingers, impaired movements, changes in hand configuration, slipping trajectories could be seen.

Stereologic measurement was used to quantify the assessment of the contact area. This valid and reliable method was found to be effective to estimate the area accurately and efficiently. Briefly, the method itself was able to produce an objective data for getting knowledge of hand interaction with the object in clinic without making the measurement complicated and the child scare of the process. (Bu paragrafa referans gerekir)

Total contact area was found to be less for the impaired hand. Pouydebat et al. showed that flattening and impaired positioning of the hand make contact area lesser in children with CP (20). Movement pattern was expected to be worse with the impaired hand, however unimpaired hand also showed differences compared to healthy subjects. Irregularity between hands was mostly seen with object having diameter of $2,5 \mathrm{~cm}$. To prevent the object from slipping, the index and middle fingers and the ring and little fingers exert moments of force in opposite directions about an axis of rotation created by the thumb (21). Kinematical studies in hemiplegical CP determined that impaired hand shows decreased thumb and index finger extension than other three fingers (12). In our study, contact of the thumb was higher whereas ulnar side of the 
hand were less between the impaired and unimpaired hand. This finding shows the limited use of ulnar side of the hand against adductor spasticity while holding a smaller cylindrical object. This means children with CP may try to get force from thumb while grasping, which is insufficient to show strength.

The contact pattern showed similarity with normal hand with only the $5 \mathrm{~cm}$ diameter object. Even the contact area of ulnar side was also less on the $5 \mathrm{~cm}$ diameter object, difference in contact area between hands was mostly significant with $4 \mathrm{~cm}$ diameter object. In a study $3,81 \mathrm{~cm}$ was found to be optimal size handle for achieving maximum strength for most of the participants (22). Studies showed individuals generate increased grip force rates for larger objects (22-24). Grip force distributions suggest that grip force is greatest for handle diameters when the fingertip and thumb forces work together against the palm (24). Our study showed the importance of ulnar side while generating force and impaired use of ulnar side of the impaired hand.

Children develop different force distribution and hand use for different objects when their sizes changed (25). Our findings showed characteristics of power-type grasps within cylindrical objects. In a methodological point of view, this study shows the importance of the size of the object in the analyses of grasping. In the study it can be stated that hypothenar and thenar balance is changing when the diameter of the object changes. The empirical basis for this proposal is the finding that contact area patterns changed and individual fingers were activated according to their mechanical advantage with different objects.

Clinicians generally emphasize thumb contribution in grasping since the influence of the adductor spasticity in CP (26). However hypothenar contribution should be also considered especially with objects having larger diameters. Sangole reported that the thenar and hypothenar contributions were the same for both cylindrical and spherical grasping, so they have similar hand shaping requirements (25). This means our results can be adaptable for spherical grasping which is very much used in rehabilitation by throwing ball.

The limitation of our study was the insufficient number of participants to generalize the characteristics of contact area patterns. Future studies may focus on showing differences according to age groups with large sample. The use of the assessment method with severe spasticity is difficult, therefore our results only indicate outcomes for subjects with mild spasticity. Method is also limited with certain objects allowing power grip. It is not practical for getting data of precision grips.

Adequate treatment planning is imperative, though requires an extensive knowledge of all upper limb dysfunctions. A clinical assessment, combined with objective and quantitative measurements of the hand could provide the necessary insights. Our study showed an assessment method of contact area and outcomes revealed some changes in hand configuration that may contribute to loss of hand dexterity. This knowledge can improve rehabilitation efforts towards recovering hand function.

\section{REFERENCES}

1. Feltham MG, Ledebt A, Deconinck FJ, Savelsbergh GJ. Assessment of neuromuscular activation of the upper limbs in children with spastic hemiparetic cerebral palsy during a dynamical task. Journal of electromyography and kinesiology. 2010;20(3):44856.

2. Eliasson AC, Gordon AM, Forssberg H. Basic coordination of manipulative forces of children with cerebral palsy. Developmental Medicine \& Child Neurology. 1991;33(8):661-70.

3. Arner M, Eliasson A-C, Nicklasson S, Sommerstein K, Hägglund G. Hand function in cerebral palsy. Report of 367 children in a population-based longitudinal health care program. The Journal of hand surgery. 2008;33(8):1337-47.

4. Trombly CA. Deficits of reaching in subjects with left hemiparesis: a pilot study. American Journal of Occupational Therapy. 1992;46(10):887-97.

5. Steenbergen B, Meulenbroek RG, Rosenbaum DA. Constraints on grip selection in hemiparetic cerebral palsy: effects of lesional side, end-point accuracy, and context. Cognitive Brain Research. 2004;19(2):145-59.

6. Coluccini M, Maini ES, Martelloni C, Sgandurra G, Cioni G. Kinematic characterization of functional reach to grasp in normal and in motor disabled children. Gait \& posture. 2007;25(4):493501.

7. Kreulen M, Smeulders M, Veeger H, Hage J. Movement patterns of the upper extremity and trunk associated with impaired forearm rotation in patients with hemiplegic cerebral palsy compared to healthy controls. Gait \& posture. 2007;25(3):485-92.

8. Mackey AH, Walt SE, Lobb GA, Stott NS. Reliability of upper and lower limb three-dimensional kinematics in children with hemiplegia. Gait \& posture. 2005;22(1):1-9.

9. Reid S, Elliott C, Alderson J, Lloyd D, Elliott B. Repeatability of upper limb kinematics for children with and without cerebral palsy. Gait \& posture. 2010;32(1):10-7.

10. Jaspers E, Desloovere K, Bruyninckx H, Klingels K, Molenaers G, Aertbeliën E, et al. Three-dimensional upper limb movement characteristics in children with hemiplegic cerebral palsy and typically developing children. Research in developmental disabil- 
ities. 2011;32(6):2283-94.

11. Jaspers E, Feys H, Bruyninckx H, Harlaar J, Molenaers G, Desloovere K. Upper limb kinematics: development and reliability of a clinical protocol for children. Gait \& posture. 2011;33(2):279-85.

12. Rönnqvist L, Rösblad B. Kinematic analysis of unimanual reaching and grasping movements in children with hemiplegic cerebral palsy. Clinical Biomechanics. 2007;22(2):165-75.

13. Wong YJ, Whishaw IQ. Precision grasps of children and young and old adults: individual differences in digit contact strategy, purchase pattern, and digit posture. Behavioural brain research. 2004;154(1):113-23.

14. Jaspers E, Desloovere K, Bruyninckx H, Molenaers G, Klingels $\mathrm{K}$, Feys $\mathrm{H}$. Review of quantitative measurements of upper limb movements in hemiplegic cerebral palsy. Gait \& posture. 2009;30(4):395-404.

15. Kamakura N, Matsuo M, Ishii H, Mitsuboshi F, Miura Y. Patterns of static prehension in normal hands. The American journal of occupational therapy: official publication of the American Occupational Therapy Association. 1980;34(7):437-45.

16. Canan S, Şahin B, Odacı E, Ünal B, Aslan H, Bilgiç S, et al. Toplam hacim, hacim yoğunluğu ve hacim oranlarının hesaplanmasında kullanılan bir stereolojik yöntem: Cavalieri prensibi. THBV Türkiye Klinikleri Tıp Bilimleri Dergisi. 2002;22:7-14.

17. Pazvant G, Sahin B, Kahvecioglu KO, Gunes H, Ince NG, Bacinoglu D. The volume fraction method for the evaluation of kidney: $A$ stereological study. Ankara Üniv Vet Fak Derg. 2009;56:233-9.

18. Eliasson A-C, Krumlinde-Sundholm L, Rösblad B, Beckung E, Arner M, Öhrvall A-M, et al. The Manual Ability Classification System (MACS) for children with cerebral palsy: scale devel- opment and evidence of validity and reliability. Developmental Medicine \& Child Neurology. 2006;48(07):549-54.

19. Gordon AM, Schneider JA, Chinnan A, Charles JR. Efficacy of a hand-arm bimanual intensive therapy (HABIT) in children with hemiplegic cerebral palsy: a randomized control trial. Developmental Medicine \& Child Neurology. 2007;49(11):830-8.

20. Pouydebat E, Gorce P, Coppens Y, Bels V. Biomechanical study of grasping according to the volume of the object: human versus non-human primates. Journal of biomechanics. 2009;42(3):26672.

21. Zatsiorsky VM, Gregory RW, Latash ML. Force and torque production in static multifinger prehension: biomechanics and control. II. Control. Biological cybernetics. 2002;87(1):40-9.

22. Edgren CS, Radwin RG, Irwin CB. Grip force vectors for varying handle diameters and hand sizes. Human Factors: The Journal of the Human Factors and Ergonomics Society. 2004;46(2):244-51.

23. Gordon AM, Duff SV. Fingertip forces during object manipulation in children with hemiplegic cerebral palsy. I: anticipatory scaling. Developmental Medicine \& Child Neurology. 1999;41(3):166-75.

24. Seo NJ, Armstrong TJ, Ashton-Miller JA, Chaffin DB. The effect of torque direction and cylindrical handle diameter on the coupling between the hand and a cylindrical handle. Journal of biomechanics. 2007;40(14):3236-43.

25. Sangole AP, Levin MF. Arches of the hand in reach to grasp. Journal of biomechanics. 2008;41(4):829-37.

26. Davids JR, Sabesan VJ, Ortmann F, Wagner LV, Peace LC, Gidewall MA, et al. Surgical management of thumb deformity in children with hemiplegic-type cerebral palsy. Journal of Pediatric Orthopaedics. 2009;29(5):504-10. 